\title{
CONVERSES OF JESSEN'S INEQUALITY ON TIME SCALES II
}

\author{
J. BARIĆ, R. JAKŠIĆ AND J. PEČARIĆ
}

Abstract. We obtain new refinements of converse Jessen's inequality with respect to the multiple Lebesgue delta integral. The applicability of our results is illustrated in refinements of converse inequalities regarding monotonicity properties of generalized means, power means and some refinements of converse Hölder's inequality, which are all proved in the time scale setting.

Mathematics subject classification (2010): 26D15, 34A40, 34N05. inequality.

Keywords and phrases: Time scale, linear functional, Jessen's inequality, converses, means, Hölder's

\section{REFERENCES}

[1] R. P. Agarwal, M. Bohner and A. Peterson, Inequalities on time scale: a survey, Math. Inequal. Appl. 4, 4 (2001), 535-557.

[2] M. Anwar, R. BIBI, M. Bohner ANd J. PeČArić, Integral inequalities on time scales via the theory of positive linear functionals, Abstract and Applied Analysis 2011, (2011).

[3] R. BIBI, M. Bohner AND J. PEČARIĆ, Cauchy-type means and exponential and logaritheoremic convexity for superquadratic functions on time scales, Ann. Funct. Anal. 6, 1 (2015), 59-83.

[4] J. BARić, R. Bibi, M. Bohner And J. PeČARić, Time scales integral inequalities for superquadratic functions, J. Korean Math. Soc. 50, 3 (2013), 465-477.

[5] J. BARIĆ, M. BOHNER, R. JAKŠIĆ AND J. E. PEČARIĆ, Converses of Jessen's inequality on time scales, Mathematical Notes 98, 1 (2015), 11-24.

[6] M. Bohner And A. Peterson, Dynamic Equations on Time Scales, Biremarkhäuser, Boston, Basel, Berlin, 2001.

[7] P. R. Bees ACK And J. E. PeČARIĆ, On Jessen's inequality for convex functions, J. Math. Anal. Appl. 110, 2 (1985), 536-552.

[8] M. Bohner And G. Sh. Guseinov, Multiple integration on time scales, Dynamic Systems and Applications 14, 3-4 (2005), 579-606.

[9] M. Bohner And G. Sh. Guseinov, Multiple Lebesgue integration on time scales, Advances in Difference Equations 2006, Article ID 26391, (2006), 13 pages.

[10] M. Bohner, A. Nosheen, J. Pečarić And A. Younus, Some dynamic Hardy-type inequalities with general kernel, J. Math. Inequal. 8, 1 (2014), 185-199.

[11] S. S. DRAGOMIR, Bounds for the deviation of a function from the chord generated by its extremities, Bull. Aust. Math. Soc. 78, 2 (2008), 225-248.

[12] G. H. Hardy, J. E. Littlewood, G. Polya, Inequalities 1sted. and 2nd ed. Cambridge University Press, Cambridge, England, (1934, 1952).

[13] S. HiLger, Ein Maßkettenkalkül mit Anwendung auf Zentrumsmannigfaltigkeiten, Phd. D. thesis, Universität Würzburg, 1988.

[14] S. HiLger, Analysis on measure chains - a unified approach to continuous and discrete calculus, Results Math. 18, 1-2 (1990), 18-56.

[15] S. Hilger, Differential and difference calculus unified, Nonlinear Anal. 30, 1 (1997), 143-166.

[16] R. JAKŠIĆ AND J. E. PEČARIĆ, New converses of the Jessen and Lah-Ribarič inequalities II, J. Math. Inequal. 7, 4 (2013), 617-645.

[17] R. JAKŠIĆ AND J. E. PEČARIĆ, New converses of the Jessen and Lah-Ribarič inequalities III, submitted. 
[18] M. KlaričIĆ, J. E. PeČArić, J. Perić, On the converse Jensen inequality, Applied Mathematics and Computation 218, (2012), 6566-6575.

[19] B. Kaymakcalan, V. Lakshmikantham and S. Sivasundaram, Dynamic Systems on Measure Chains, Kluwer Academic Publishers, Dordrecht, (1996).

[20] P. LAH, M. Ribarič, Converse of Jensen's inequality for convex functions, Univ. Beograd. Publ. Elektrotehn. Fak. Ser. Mat. Fiz. 412-460, (1973), 201-205.

[21] J. E. PeČARIĆ, Konveksne funkcije: Nejednakosti, Naučna knjiga, Beograd, (1987).

[22] J. Pečarić, F. Proschan and Y. C. Tong, Convex functions, Partial Orderings and Statistical Applications, Academic Press, Inc. (1992).

[23] F. H. Wong, C. C. YeH AND W. C. Lian, An extension of Jensen's inequality on time scales, Adv. Dyn. Syst. Appl. 1, 1 (2006), 113-120. 